Finance and Economics Discussion Series

Divisions of Research \& Statistics and Monetary Affairs

Federal Reserve Board, Washington, D.C.

\title{
Outstanding Outsourcers: A Firm-and Plant-Level Analysis of Production Sharing
}

\section{Christopher Johann Kurz}

2006-04

NOTE: Staff working papers in the Finance and Economics Discussion Series (FEDS) are preliminary materials circulated to stimulate discussion and critical comment. The analysis and conclusions set forth are those of the authors and do not indicate concurrence by other members of the research staff or the Board of Governors. References in publications to the Finance and Economics Discussion Series (other than acknowledgement) should be cleared with the author(s) to protect the tentative character of these papers. 


\title{
Outstanding Outsourcers: A Firm- and Plant-Level Analysis of Production Sharing
}

Christopher Johann Kurz ${ }^{1}$

Board of Governors of the Federal Reserve System

November 2005

JEL No.: F10, F14, L24

KEY WORDS: Outsourcing, Productivity, Exporter, Plant-Level, and Multinational

\begin{abstract}
$\underline{\text { Abstract }}$
This paper examines the differences in characteristics between outsourcers and nonoutsourcers with a particular focus on productivity. ${ }^{2}$ The measure of outsourcing comes from a question in the 1987 and 1992 Census of Manufactures regarding plant-level purchases of foreign intermediate materials. There are two key findings. First, outsourcers are "outstanding." That is, all else equal, outsourcers tend to have premia for plant and firm characteristics, such as being larger, more capital intensive, and more productive. One exception to this outsourcing premia is that wages tend to be the same for both outsourcers and non-outsourcers. Second, outsourcing firms, but not plants, have significantly higher productivity growth.
\end{abstract}

\footnotetext{
${ }^{1}$ Christopher J. Kurz, Division of Research and Statistics, Federal Reserve Board, Washington DC 20551. The views expressed in this paper are solely the responsibility of the author and should not be interpreted as reflecting the views of the Board of Governors of the Federal Reserve System or of any other employee of the Federal Reserve System. Contact information for the author: christopher.j.kurz@,frb.gov, (202)452-3086, (202)736-1937 (fax).

2 The research in this paper was conducted while the author was a special sworn status researcher of the U.S. Census Bureau at the MCRDC. Research results and conclusions expressed are those of the author and do not necessarily reflect the views of the Census Bureau. This paper has been screened to insure that no confidential data are revealed. Support for this research at the MCRDC from the NSF (award nos.SES-0004322 and ITR0427889) is gratefully acknowledged. Special thanks accrue to Ben Chabot, James Levinsohn, Mine Senses, Ken Scheve, Linda Tesar, to the many seminar participants at the 2004 EIIT conference, the Midwest Annual Meetings, and to colleagues at the University of Michigan and Federal Reserve.
} 


\section{INTRODUCTION}

Countries are increasingly specializing in stages of production instead of specific goods. This fragmentation of production processes-known as outsourcing or production sharingtends to boost trade in intermediate inputs, leading to the foreign assembly of domestic parts, or alternatively, the domestic assembly of foreign parts. Increased outsourcing has sparked debate in federal and state governments and the popular press. Much of the discourse has been increasingly hostile toward outsourcing organizations. The Congress has limited outsourcing on federal contracts, while thirty-seven state legislatures have limited outsourcing or are currently proposing legislation to do so. Perhaps as a result of negative press coverage, and possibly causing some of the anti-outsourcing legislation, 73 percent of Americans believe that the government should discourage companies from hiring workers in foreign countries. ${ }^{1}$

However, surprisingly little is known about the types of firms and establishments that outsource and the effects of outsourcing on these organizations. In this paper I intend to fill this gap buy using plant-level U.S. manufacturing data to identify differences in the characteristics of outsourcers and non-outsourcers, with a particular focus on two productivity-related aspects of outsourcing. First, I test whether organizations can be sorted into outsourcing or nonoutsourcing groups on the basis of their productivity levels. Second, I examine differences in the rates of productivity growth between outsourcers and non-outsourcers.

On one hand, outsourcing organizations could be marginal in that they are struggling to remain profitable in a world of increasing competition. On the other hand, these organizations could be larger and more productive than their non-outsourcing counterparts. Focusing on characteristics and productivity will help make such a distinction, which has important policy and research implications.

Much of the academic literature on production sharing is theoretical, looks at the relationship between outsourcing and wages, or measures the importance of outsourcing in the global economy. ${ }^{2}$ The current body of theoretical work makes predictions about outsourcing at the firm- and plant-levels, but a lack of microdata has restricted empirical investigations into outsourcing at this level of disaggregation.

Testing whether productivity differs between outsourcers and non-outsourcers rests

${ }^{1}$ Economist (2004), YouGov poll, July 17, 2004, p.29.

${ }^{2}$ For studies on the relationship of trade and wages, see Feenstra and Hanson (1996, 1999, and 2002). For studies on the importance of outsourcing, see Feenstra (1998), Yeats (2001), Campa and Goldberg (1997) and Hummels, Ishii, and Yi (2001). 
heavily upon the work of Antràs and Helpman (2004). Antràs and Helpman (2004) extend a framework put forth in Grossman and Helpman $(2002,2005)$ to incorporate productivity and its implications for a firm's decision to outsource. In their analysis, an exogenous productivity distribution and cost differences drive firms' outsourcing behavior. ${ }^{3}$ In equilibrium, different types of firms choose to outsource from either domestic or foreign sources on the basis of their productivity draws. Cost differences cause higher-productivity firms to outsource from foreign sources, while lower-productivity firms outsource domestically. The intuition for such sorting derives from the inability of low-productivity firms' to cover the fixed costs of foreign outsourcing. This implication will allow for a test of productivity and its relation to outsourcing-specifically, whether high-productivity firms are more likely to partake in foreign outsourcing.

In addition, Feenstra, Markusen, and Zeile (1992) and Ethier (1982) provide frameworks in which productivity changes can be traced to input selection. Although these papers do not specifically address production sharing, they are directly applicable to the issues faced by firms and plants that outsource. Ethier (1982) shows that new intermediate inputs allow for greater specialization in resource use, which in turn leads to higher productivity. Feenstra, Markusen, and Zeile (1992) continue this thread in the literature by identifying the contributions to growth arising from increased quantities of inputs and from an increased range of input selection. Growth in expenditure on new inputs for a firm or plant should be positively correlated with total factor productivity. This result is verified through tests on a sample of South Korean conglomerates. Feenstra revisits these issues six years later, stating that " $[\mathrm{t}]$ he same productivity gains discussed in this literature apply when firms shift their production activities across countries" (Feenstra, 1998, p.22)

The aforementioned papers supply the framework for the following analysis of outsourcing. Antràs and Helpman (2004) present a testable hypothesis regarding an organization's productivity level and its outsourcing behavior. Feenstra, Markusen, and Zeile (1992) and Ethier (1982) provide the impetus for analyzing productivity dynamics over time.

Empirical work on outsourcing at the plant or firm level for the United States is limited by the available data. One paper that overcomes the current lack of data is Hanson, Mataloni, and Slaughter (2003), which examines the foreign determinants of imported intermediate inputs.

\footnotetext{
${ }^{3}$ This result is similar to Melitz's finding that exogenous productivity distribution drives export behavior (2003).
} 
The authors find that demand for imported intermediate inputs is negatively correlated with trade costs, and sensitive to labor-costs and host country characteristics. ${ }^{4}$

Previous work on exporters and multinationals is related to research on outsourcing. ${ }^{5}$ The exporting literature finds a premium for the characteristics of exporters relative to those of non-exporters. Exporters are "exceptional." They are larger, have higher value added and output, pay higher wages to skilled and unskilled workers, employ more capital and skilled workers, and have higher static levels of productivity.

The literature on multinationals mirrors that on exporters. Two papers by Doms and Jensen (1998a, 1998b) establish that multinationals operating in the United States are larger, have higher output, wages, and productivity, and are more capital- and skill-intensive than are nonmultinationals operating in the United States. Similar to the exporting and multinational literature, I will test whether such premia exist for outsourcers, while controlling for exporter and multinational status.

There are three main findings in this paper. First, outsourcers are "outstanding." There are premia for outsourcers over non-outsourcing organizations for plant and firm characteristics, with the exception of wages paid to workers. Second, organizations that outsource have higher productivity, even after controlling for firm and plant characteristics. Finally, firm-level productivity growth is significantly higher for outsourcers, a result that does not hold at the plant level.

There are four additional sections. Section 2 outlines the data and methodology. Section 3 provides descriptive statistics and determines whether or not outsourcers are "outstanding." Section 4 presents the productivity estimation results and section 5 concludes.

\section{DATA AND METHODOLOGY}

\section{Data}

This paper uses the Longitudinal Research Database (LRD) and the Large Company Survey (LCS) to investigate the characteristics of and productivity-related implications for outsourcing

\footnotetext{
${ }^{4}$ Two recent papers use international plant-level data. Girma and Görg (2004) analyze domestic and international outsourcing in the UK, as measured by the cost of industrial services received relative to a total wage bill. The authors find high wages are positively related to outsourcing, chemical and engineering sector productivity is positively related to outsourcing, and foreign-owned firms have higher levels of outsourcing. Görg, Hanley, and Strobl (2004) use a similar approach to measuring outsourcing in for Irish manufacturers, finding outsourcing and exporting plants experience positive productivity gains.

${ }^{5}$ For work on exporters, see Bernard and Jensen (1995, 1999, 2004a, 2004b).
} 
organizations. The Census of Manufactures (CMF) and the Annual Survey of Manufactures (ASM) longitudinally combine to form the LRD from 1972 to 2002. The LRD consists of confidential census data that provide microlevel economic information.

The CMFs of 1987 and 1992 queried plants regarding the cost of the foreign content of materials used in production. The question asks, "Does this establishment use materials purchased or transferred from foreign sources?" If the survey respondent answers "yes" to this question, the respondent is further asked to report the percentage of input materials that come from sources outside the United States. ${ }^{6}$ These data provide an excellent plant-level proxy for outsourcing that allows the following analysis to account for differences in production-sharing activities between organizations.

The census's outsourcing questions are limited in that they address only one specific variant of production sharing - the purchase of foreign input materials. Plants and firms that reimport and finish products that were initially produced in the United States and that contain value added from foreign manufacturers are not flagged in these surveys. Also, plants that directly export materials for finishing abroad are not delineated as outsourcers in the samples for the 1987 and 1992 CMFs. These omissions do not detract from the testable hypotheses. Defining organizations as non-outsourcers, when in fact they should be considered outsourcers, will bias the following tests toward insignificance.

In addition, I merge the LRD with the LCSs of 1987 and 1992 to test the robustness of my outsourcing measure to the inclusion of a multinational status indicator. The Census Bureau sent the LCS, or ES9100-Enterprise Summary Report, to domestic firms with 500 or more employees during Economic Census years. The LCS reports a firm's plant count, employment, payroll, sales, and assets and expenditures. I use the assets information to create an indicator of multinational status.

I create an unbalanced panel from 1987 to 1996 for the following analysis. Capital stock data are constructed using a perpetual inventory method for a larger time frame, 1982 to $1996 .^{7}$

\section{Defining Outsourcing}

\footnotetext{
'Input materials, as defined by the survey, are the cost of materials and parts. This measure includes the cost of all materials, raw materials, containers, and scrap and supplies but excludes that of energy, contract work, and resales. The measure also includes the cost of materials owned by the reporting establishment but consumed by other companies to make products under contract.

7 See appendix for a description of capital stock construction.
} 
This paper uses a CMF question regarding an establishment's purchase of foreign content in intermediate inputs as a proxy for outsourcing. Outsourcing is trade in intermediate goods, or as defined by Krugman (1995), it is the geographic separation of activities involved in producing a good (or service) across two or more countries. This definition requires further exposition. I take three approaches to ensure that the variable for foreign content of inputs actually captures outsourcing. I call these approaches the broad, restricted- $A$, and restricted-B outsourcing metrics.

Strictly interpreting outsourcing as the purchase of foreign intermediate goods leads to the broad measure of outsourcing. This approach defines outsourcing as the affirmative response to the survey question of whether the plant purchases foreign content. The value of an organization's outsourcing can be derived by multiplying the percentage of foreign content in input materials by the value of total inputs. Feenstra and Hanson (1996) use a similar approach at the industry level when measuring outsourcing as the share of imported intermediate inputs in total purchases of materials.

Two issues arise when defining outsourcing as the purchase of intermediate goods from other countries. First, the outsourcing proxy should avoid capturing the purchase of raw materials from foreign sources as outsourcing. For example, the importation of pineapples by Dole for processing should not be considered outsourcing. Second, I wish to compare and contrast the actions of establishments and firms that outsource with those that do not outsource within industries known for their outsourcing behavior. Labeling an organization an outsourcer according to whether it purchases intermediate goods from abroad may result in the inclusion of establishments and firms from industries not known to actively participate in outsourcing.

Two sets of restrictions on the data help resolve both of these issues. The restrictions are called restricted- $A$ and restricted- $B$. The restricted-A set selects the top ten two-digit outsourcing industries from Feenstra and Hanson's four-digit outsourcing measure (1996). ${ }^{8}$ Each four-digit industry is aggregated to the two-digit level and ranked by the amount of outsourcing. The top ten two-digit outsourcing industries are taken as a subset from the twenty two-digit industries. Table 1 presents the two-digit Standard Industrial Classification codes and the definition of the restricted-A measure of outsourcing. This measure eliminates the industries that purchase raw materials_-for example, food and kindred products, tobacco manufacturing, petroleum and coal products, and lumber and wood products_-and focuses on the two-digit sectors known to 
outsource.

The restricted-B set uses the Benchmark Input-Output accounts to restrict the set of plants and firms within four-digit Standard Industrial Classifications (SICs) that do not purchase large quantities of raw material intermediate inputs. Raw materials are defined, in this context, as intermediate inputs from the industrial classifications of agriculture, forestry, and fishing and mining. The restricted-B set excludes seventy-two four-digit industries and three three-digit industries with more than 5 percent of their intermediates composed of raw materials. For example, the primary nonferrous metals industry (SIC 3339), which purchases 60 percent of its intermediates from mining industries, is excluded. I present results for the unrestricted, or broad, measure of outsourcing, which includes all manufacturers, plus results for the smaller samples that exclude the industries eliminated by using the restricted-A and restricted-B methods. ${ }^{9}$

\section{Firms and Plants}

It may sound obvious, but the majority of research using plant-level data is performed at the plant level. This allows the researcher to make the most of the heterogeneity within the microdata, but may not be the optimal level of disaggregation for an analysis of outsourcing. The decision to shut down a part of a production process and purchase inputs from overseas is most likely made at the firm level, where top management has the best information about relative productivity and profitability between units within an organization. The following work includes a plant-level analysis, while also looking at the same questions at the firm level.

Firms are defined as individual establishments under common ownership. For example, say we are looking at a sample of 10 plants. 6 of these plants are multi-unit establishments and 4 are single-unit establishments. Multi-unit establishments are part of an organization of plants that have common ownership. The four single-unit establishments are also individual firms. Let us also say that of the 6 multi-unit establishments, 4 are owned by firm $\mathrm{A}$ and 2 by firm B. Aggregating this data to the firm level would lead to 6 firms from 10 plants. Firm A would be an aggregation over 4 establishments, Firm B would be the aggregation over 2 establishments, while the remaining 4 plants are also defined as firms.

\section{Estimating Productivity-Choice of Production Function}

${ }^{9}$ The following analysis was also performed using the top ten two-digit industries from the more restrictive narrow measure of Feenstra and Hanson (1999). The results were robust to either measure. 
I use total factor productivity to measure plant- and firm-level productivity. The choice of the form of the production function matters when analyzing the productivity differences between outsourcing and non-outsourcing establishments. For example, consider the case of a production function, in logs, of the following form:

$$
Y=\beta_{1}+\beta_{2} L+\beta_{3} K+\beta_{4} M+\varepsilon,
$$

where $Y$ is output, $L$ is labor, $K$ is capital, $M$ is intermediate inputs, and total factor productivity is

$$
T F P=Y-\left(\hat{\beta}_{1}+\hat{\beta}_{2} L+\hat{\beta}_{3} K+\hat{\beta}_{4} M\right) .
$$

When measuring productivity at the plant or firm level, the production function estimation calculates coefficients on the basis of average levels of labor, capital, and intermediate inputs usage at the industry level — that is, production function estimates are made with the assumption that firms have identical technology (cost shares) at an industry level. Outsourcing and non-outsourcing organizations will not have identical technology, especially in terms of intermediate inputs usage. Large differences in $M$ may translate into large differences in TFP. In other words, using output and intermediate inputs to estimate a production function may not be as robust to differences in technology across producers.

To avoid problems arising from differences in intermediate inputs usage, I estimate a value-added production function that takes the following form:

$$
V A=\beta_{1}+\beta_{2} L+\beta_{3} K+\varepsilon,
$$

with total factor productivity calculated as

$$
T F P=V A-\left(\hat{\beta}_{1}+\hat{\beta}_{2} L+\hat{\beta}_{3} K\right) .
$$

The use of value added will circumvent differences in productivity arising from differences in intermediate input usage, but an alternative problem may arise if there is a systematic bias in value-added measurement. Value added is the value of output less the value of intermediate inputs for an individual plant. If internationally vertically integrated plants receive inputs from abroad that are transferred and not purchased (or discounted), there may be a systematic positive bias in value-added measurements. This bias would arise through a downward bias in the value of intermediate input costs.

The CMF and ASM survey collection methods avoid this possible problem through the way in which plants are queried regarding the valuation of materials consumed. Specifically, the survey form asks plants that receive materials from other plants within the same company to 
report those materials "at the value assigned by the shipping plant, plus the cost of freight and other handling charges."

What we really care about when estimating productivity is the ability to transform inputs into a level of output. This measure should change when either more or less output is created from a given level of inputs, not as a result of differences in the usage or measurement of intermediate inputs.

\section{Estimating Productivity-Levinsohn and Petrin}

I estimate total factor productivity for both plants and firms using Levinsohn and Petrin's methodology (2003) to control for simultaneity between unobservable productivity and the observable input choices. A firm- and plant-level analysis is conducted because the decision to shut down part of a production process and purchase foreign inputs is most likely made at the firm level, where top management has the best information about relative productivity and profitability between units within an organization. ${ }^{10}$

The estimated production function in logs is

$$
y_{i t}=\beta_{o}+\beta_{p} p_{i t}+\beta_{n p} n p_{i t}+\beta_{k} k_{i t}+\omega_{i t}+\eta_{i t},
$$

where $y_{i t}$ is value added for plant or firm $i$ at time $t, p_{i t}$ and $n p_{i t}$ represent the variable inputs of production workers and nonproduction workers, $k_{i t}$ is capital, and $\beta$ is an input elasticity. ${ }^{11}$ The sum $\omega_{i t}+\eta_{i t}$ represents composite error, where $\omega_{i t}$ serves as a transmitted plant-specific efficiency that affects plant decisions and $\eta_{i t}$ is an independently and identically distributed shock not known to the econometrician or a firm-level decisionmaker. $\quad T F P_{i t}=\omega_{i t}+\eta_{i t}$ is the productivity term of interest.

The approach of Levinsohn and Petrin (2003) (hereafter, LP) solves the simultaneity problem by using a proxy for the transmitted plant-specific efficiency. The specific intermediate input chosen as a proxy for the unobservable shock is electricity. An alternative means of controlling for simultaneity is the approach of Olley and Pakes (1996) (hereafter, OP), which presents conditions in which investment acts as a successful proxy for $\omega_{i t}$.

Two benefits of LP over OP lead to the decision to use intermediate inputs, as opposed

\footnotetext{
${ }^{10}$ Firms are defined as individual plants under common ownership.

${ }^{11}$ The productivity residuals were also calculated using ordinary least squares. The following results were robust for each approach.
} 
to investment, as the control for the unobservable productivity shock. First, the investment proxy is valid only for plants that report nonzero investment. The case in which investment is equal to zero is especially significant in terms of using developing-country, plant-level data sets. ${ }^{12}$ Surprisingly, in the 1987-96 panel of plants constructed from the CMF and the ASM, 10 percent of the establishments are missing investment data, whereas 4 percent of plants are missing information on purchased electricity. The second benefit of the LP approach over the OP approach arises if adjustment costs are nonconvex. Nonconvexities in investment demand may lead to nonresponses or partial responses in investment to a given productivity shock. ${ }^{13}$

\section{Empirical Specifications}

The following empirical specifications test for differences in productivity between outsourcing and non-outsourcing organizations. Each test is performed on both firms and plants for the restricted and unrestricted samples. I use a probit specification to test for an increase in the probability of outsourcing based on the level of productivity, and I employ a productivity change framework to explore whether outsourcing organizations differ in productivity growth at the firm or plant level.

\section{Probit Analysis}

Once productivity is estimated, I use a probit specification to test whether plants and firms with higher productivity are more likely to outsource. I estimate LP productivity using the entire panel from 1987 to 1996. After estimating productivity for each year in the panel, I pool the 1987 and 1992 cross sections for the probit analysis. The specification is

$$
\operatorname{Pr}\left(P S_{i t}=1\right)=\Phi\left(\beta_{1}+\beta_{2} T F P_{i t}+\mathbf{X}_{i t} \boldsymbol{\beta}\right),
$$

where $P S_{i t}=1$ if an organization outsources and $P S_{i t}=0$ otherwise, $T F P_{i t}$ is total factor productivity, and $X_{i t}$ is a set of controls that vary across specifications. The controls include time dummies, size, export status, skill composition, industry, multi-unit status, and location dummies. I measure an organization's size with total employment. Export status is a dummy variable equal to one if the organization has positive exports during the year of interest. The skill composition of an organization's labor force is measured by the ratio of nonproduction workers

\footnotetext{
${ }^{12}$ For example, data sets from Chile, Turkey, Colombia, Mexico, and Indonesia sometimes indicate that more than half of the establishments have reported zero investment.
} 
to total employment. Industry dummies are included in the specification at the four-digit SIC level. A multi-unit status indicator equals one or zero on the basis of whether an establishment or firm belongs to a larger organization composed of several establishments. State dummies control for location.

The expected coefficient on $T F P_{i t}$ for both plants and firms is positive. If the theoretical prediction of Antràs and Helpman (2004) holds, then higher productivity levels allow firms and plants to cover the fixed costs of choosing the outsourcing organizational form.

\section{Productivity Changes}

Outsourcing may lead to changes in productivity over time through new intermediate inputs that allow for greater specialization. We cannot say much about the transition from a nonoutsourcing organization to an outsourcing one because of the limitations of using only two sample years for the foreign content of intermediate inputs. However, we can compare the productivity growth rates of outsourcers and non-outsourcers, though questions regarding causality are left unanswered.

Comparisons of the growth rates of exporters and non-exporters have recently been made in the literature. ${ }^{14}$ For the United States, no significant evidence has been found to support higher productivity growth for exporting establishments. In some cases, exporter status has been found to have a negative effect on productivity growth. I employ a specification similar to that used by Bernard and Jensen (1999, 2004a) to test for differences in productivity growth rates between outsourcing and non-outsourcing establishments. Specifically,

$$
\Delta \ln \left(T F P_{i t+1}\right)=\theta_{0}+\theta_{1} P S_{i t}+\mathbf{X}_{i t} \boldsymbol{\theta}+\boldsymbol{\varepsilon}_{i t},
$$

where the dependent variable is log differences in the LP measure of productivity, $P S_{i t}$ is an indicator of production-sharing behavior, and $\mathbf{X}_{i t}$ is a matrix of controls that are similar to those in specification (6) and that include time dummies.

One problem that arises in the estimation of (7) is that $P S_{i t}$ does not vary over time. During census years, the survey respondents queried regarding their foreign content usage are a subset of the ASM sample. That sample changes every five years, so there is only minimal information on the transition between outsourcing and non-outsourcing by organizations;

\footnotetext{
${ }^{13}$ Doms and Dunne (1998) describe nonconvexities in manufacturing investment data from the U.S. census.
}

${ }^{14}$ For examples using census microdata, see Bernard and Jensen (1999 and 2004a). 
therefore, I set $P S_{i t}=1$ for all $t$ if a firm or plant purchases foreign content in either 1987 or 1992. Given this restriction, (7) will allow us to test for differences in the productivity growth rates between outsourcing and non-outsourcing firms and plants. As firms outsource parts of their production processes, productivity should increase as the inefficient and costly divisions are closed down, leading to a positive expected coefficient $\theta_{1}$ for firms.

\section{DESCRIPTIVE STATISTICS AND “OUTSTANDING” OUTSOURCERS}

\section{Descriptive Statistics}

The Census Bureau surveyed more than 350,000 plants for each year of the 1987 and 1992 CMF and asked a subsample of roughly 45,000 ASM plants about their purchases of foreign intermediate inputs. ${ }^{15}$ From the group of plants that answered, I dropped the respondents that did not know whether their establishment purchased intermediate inputs containing foreign content. Answers that were inconsistent with the choices on the survey forms were also removed from the sample. ${ }^{16}$ Table 2 presents the results of these selection criteria. The 1987 and 1992 samples retained 34,649 and 39,579 plants, respectively. The number of plants that responded positively to the query of whether they purchase foreign inputs was 10,321 for 1987 and 9,423 for 1992. Thus, the fraction of survey respondents defined as "outsourcers" decreased from 30 percent in 1987 to 24 percent in 1992.

The decrease in outsourcing plants from 1987 to 1992 is surprising given the overall trend toward outsourcing. One reason for a decrease in the number of outsourcers may be outsourcing's role in smoothing production throughout the business cycle. ${ }^{17}$ The brief recession in the early 1990s may account for the decline in the share of outsourcing establishments. However, the fraction of outsourced intermediates increased from 1987 to 1992. The amount of outsourced intermediates across all establishments rose from 9.15 percent to 9.92 percent of parts and materials purchases. For organizations that outsource, this number increased from 17.79 percent to 18.38 percent.

In order to further understand the data used within this analysis, I decomposed the

\footnotetext{
${ }^{15}$ The ASM surveys roughly $20 \%$ of all manufacturing plants with about $70 \%$ of all manufacturing output. ${ }^{16}$ Only 3 valid answers were recorded. Establishments that responded " 1 " purchased foreign content. Those that answered " 2 " did not purchase foreign content. Answers of " 0 " were for establishments that did not know if purchases or foreign content were made or not. In some cases answers of 3 or 5 were in the data, but were discarded because they did not correspond to a selection on the survey form.

${ }^{17}$ For an analysis of the reasons for a firm's decision to contract work out, see Abraham and Taylor (1996).
} 
pooled data by plants and output into different types of organizations. Table 3 summarizes the fraction of plants and fraction of output in outsourcing, exporting, both, or neither. In terms of the number of plants, half the plant observations do not outsource or export, 27 percent of the plants outsource, and 41 percent export. How does the plant count translate into the fraction of total output within the sample used for this analysis? Table 3 also shows that only about a quarter of the fraction of total output is produced by plants that do not outsource or export. Outsourcers produce 54 percent of the output and exporters 64 percent, with outsourcers and exporters producing 41 percent.

Tables 4 and 5 present summary statistics by two-digit SIC industry. Two digit industry definitions can be found in table 1. The second column presents the total number of plants per industry. The third column provides an industry decomposition of the fraction of outsourcing plants, defined by those establishments answering yes to the purchase of foreign content in intermediate inputs. Column 4 presents the fraction of parts and materials outsourced by firms that engage in production sharing, while column 5 presents the value of foreign content inputs as a fraction of total inputs. The last four columns present employment and output for outsourcing and non-outsourcing establishments.

A ranking of the fraction of total plants that purchase foreign content (column 3) changes slightly from 1987 to 1992, but the top six industries remain the same in both years. The largest fraction of plants that outsource for both years is in tobacco, leather and leather products, instruments and related products, electrical equipment and machinery, transportation equipment industries, and miscellaneous manufacturing.

The fourth column of table 4 looks at the percentage of parts and materials outsourced, as reported on the survey form. The largest outsourcing industries in 1987 are printing and publishing, petroleum and coal, miscellaneous manufacturing, apparel, and leather products. In 1992, this ranking changes to petroleum and coal, printing and publishing, apparel, primary metal industries, food, and tobacco. The existence of tobacco, petroleum and coal, and the food and kindred products reflects that the measure of imported intermediate inputs as a proxy for outsourcing captures imports of raw materials, underscoring the importance of using the restricted measures of outsourcing as defined in section 2 .

The fourth column is most similar to Feenstra and Hanson's (1996 and 1998) broad measure of outsourcing. Comparing the ranking of the top outsourcing industries from Table 4 and 5 with a summary of Feenstra and Hanson's measure from 1990 finds 5 of the top 10 
outsourcing industries are the same across all three samples, with 1987 having 6 industries in common and 1992 containing 7 industries.

Column 5 presents a disaggregated industry summary across plants of foreign content's fraction of inputs. I take this average over plants that purchase foreign content and those that do not. Column 5 is most similar, in terms of construction, to the measure of outsourcing forwarded by Campa and Goldberg (1997). Campa and Goldberg construct a similar measure to Feenstra and Hanson, but with imported intermediates as a fraction of total production cost, including inputs and wages. "The Foreign Content Percent of Total Inputs" measure is the fraction of materials and parts purchased from abroad divided by the total value of inputs, or the sum of wages and salaries plus total non-labor input costs. Again, within the top five we see large amounts of foreign content in the tobacco, petroleum, leather, electrical and electronic equipment, and miscellaneous manufacturing industries. Comparing these measures with the tables of Campa and Goldberg (1997) 8 of the top 10 industries are the same for the respective measures of outsourcing. This means that of the two digit manufacturing industries that Campa and Goldberg (1997) report as the highest in terms of imported input share, the foreign content of inputs variable defined in tables 4 and 5 display similar results.

The last four columns of tables 4 and 5 tell an interesting story. The columns are broken down into employment and output by the plants that purchase foreign content and those that do not. Both employment and output are much larger for outsourcing establishments. The average employment across all industries is more than twice as large for both years and gross output is nearly 4 times as large in 1987 and 5 times as large in 1992. These stark differences between

plants and firms that outsource raise an interesting question. If one controls for certain plant attributes, are there significant differences between outsourcing and non-outsourcing organizations' characteristics?

\section{“Outstanding" Outsourcers}

\section{Characteristics of Plants and Firms}

A large body of evidence suggests that exporters are "exceptional" when compared with nonexporters that have similar characteristics. Are organizations that purchase foreign content smaller and less competitive, striving for a cost advantage against competition? Or, as with exporters, are they larger and more productive organizations that take advantage of international production to increase and maintain their current positions in the market? 
A first step in answering these questions is to summarize basic plant characteristics across the outsourcing proxy. Specifically, means and standard deviations for the following characteristics are presented as of 1987 for both plants and firms: total employment, total value of shipments, wages per worker, shipments and value added per worker, capital and investment per worker, and fraction of skilled workers in the labor force (tables 6 and 7). ${ }^{18}$

At the plant level, both total employment and total value of shipments are more than twice as large for outsourcers as for non-outsourcers. Wages per worker, wages per production worker, and nonproduction wages are also all higher but by only a few thousand dollars in each case. Also, shipments and value added per worker are higher. Capital per worker is also slightly larger, while investment per worker is 14 percent higher. The composition of the labor force of outsourcing establishments is 3.4 percent more skill intensive.

The disparities between outsourcing and non-outsourcing establishments increase at the firm level. The employment and shipments of outsourcing establishments are now roughly seven and ten times as large respectively. Interestingly, differences in per-worker wages have almost completely disappeared or, as in the case of nonproduction workers, have reversed.

The results are similar to the differences between exporters and non-exporters found in Bernard and Jensen's studies $(1995,1999)$, but wages stand out as an exception. Exporters seem to compensate employees more than do non-exporters overall, a difference that tends to increase at the firm level. For outsourcing establishments, wages per employee are marginally higher than non-outsourcers, a difference that almost disappears at the firm level, even for skilled labor.

Drawing conclusions regarding the differences between outsourcing and nonoutsourcing organizations requires a more formal test. The next section investigates whether these differences are statistically significant after controlling for plant and firm characteristics.

\section{Controlled OLS Regressions of Characteristics}

I test for differences in characteristics between outsourcing and non-outsourcing organizations, using the following pooled specification for 1987 and 1992:

$$
X_{i t}=\alpha+\alpha_{1} P S_{i t}+\alpha_{2} E X P_{i t}+\alpha_{3} t+\alpha_{4} \operatorname{size}_{i t}+\mathbf{X}_{i t} \theta+\varepsilon_{i t},
$$

where $X_{i t}$ is the log of the plant characteristic of interest, $P S_{i t}$ is an indicator of outsourcing

\footnotetext{
${ }^{18}$ The summary characteristics for 1992 are similar to those for 1987. Large standard deviations are an artifact of
} plant-level data sets. 
activity, $E X P_{i t}$ controls for export status of firms or plants, $t$ is a time dummy, size $e_{i t}$ is the $\log$ of total employment controlling for plant or firm size, and $\mathbf{X}_{i t}$ is a matrix of plant- or firmspecific controls for industry, location, and multi-unit status. The results of the regressions of plant characteristics on outsourcing status and controls are presented for plants and firms (table 8). ${ }^{19}$

The plant-level results in table 8 are consistent with the summary statistics presented earlier. The controlled specifications are all significant except in one case. The controlled regressions of employment and value of shipments are significantly higher at 46 percent and 66 percent respectively. ${ }^{20}$ The outsourcing dummies for total wages per worker and total wages per nonproduction worker are both significant, whereas wages paid to production workers are not significantly different for outsourcers relative to non-outsourcers. Shipments, value added, capital, and investment are all significantly higher. The difference in the skilled-worker ratio is significant too, but it denotes only a 1.8 percent difference between outsourcing and nonoutsourcing establishments.

The firm-level results in table 8 are similar to the plant-level results but have larger coefficients. The regression for production worker wages is still insignificant, as is that for nonproduction worker wages with controls. Outsourcing firms have noticeably higher levels of employment and total shipments than do non-outsourcing firms: The differentials, at 81 percent higher and 113 percent higher, are much larger than those between outsourcing and nonoutsourcing plants.

For both the plant- and firm-level regressions of characteristics, the results on the exporting dummy are consistent with the results in the "exceptional" exporter literature. The coefficient on outsourcing status, even when controlling for exporting status, mirrors the existence of an exporter premia. The disparity between the exporting and outsourcing premia arises when comparing wages for outsourcing organizations with those for non-outsourcing organizations; a lack of premia not found in the exporting literature.

Why do we observe an outsourcing premium for every plant characteristic except

\footnotetext{
${ }^{19}$ The specifications for total employment, total value of shipments, and fraction of nonproduction workers do not include the total employment control as an independent variable. The restricted-A and restricted-B subsamples have identical significance and similar coefficients.

${ }^{20}$ In terms of interpretation, the Halvorsen and Palmquist adjustment for interpreting dummy variables in semilog regressions (1980) would make employment and value of shipments 46 percent and 66 percent larger for outsourcing establishments in the controlled specifications, not 38 percent and 51 percent, the actual coefficients.
} 
production worker wages and for every firm characteristic except production and nonproduction worker wages? The reason behind the existence of wage premia for exporters, particularly wages per worker, is an open question possibly related to employee characteristics or efficiency wages. ${ }^{21}$ Interestingly enough, for this study the wage premium does not exist for outsourcers but does for exporters. One possible explanation for the lack of a premia for certain wages is that the substitution of imported intermediates for domestic production increases competition and eliminates any wage premium paid to employees. ${ }^{22}$

\section{ESTIMATION RESULTS}

\section{Probit Analysis}

The probit analysis tests whether an increase in total factor productivity raises the probability of outsourcing. I report the marginal effects from the pooled probit specifications of four specifications based on equation (6) for both plants and firms in table 9. The third specification (column 3) is repeated for the restricted-A and restricted-B samples under the "Restricted Cases" heading in columns $5-\mathrm{A}$ and $6-\mathrm{B}^{23}$

The coefficient estimates for outsourcing are all significant at the 1 percent level for both plants and firms. Higher levels of total factor productivity increase an organization's probability of outsourcing. Across all specifications, the marginal effect of productivity declines as controls are added. To interpret these results, I multiply an increase in productivity of 1 standard deviation by the marginal effect from the probit. For plants in the unrestricted cases, an increase in productivity of 1 standard deviation raises the probability of outsourcing roughly 1.4 to 2 percentage points given a standard deviation in productivity of 1.31. The restricted samples of plants see an increase in the probability from 1.6 to 1.8 percentage points given a standard deviation of 1.5. For firms, we see a much higher probability of outsourcing for an increase in productivity of 1 standard deviation. Similar increases in productivity raise the probability of outsourcing 1.7 to 3.2 percentage points for all industries and 2.1 to 3.1 percentage points for the restricted cases, given standard deviations in productivity of 0.86 and 0.96 for the unrestricted and restricted cases respectively.

\footnotetext{
${ }^{21}$ Schank, Schnabel, and Wagner (2004) find that the wage premium in linked employee-employer data for Germany disappears once employee characteristics are controlled for.

${ }^{22}$ Senses (2005) argues that the threat of outsourcing increases the elasticity of labor demand. Feenstra and Hanson (1996) argue that outsourcing has contributed to the decrease in relative demand for unskilled labor.

${ }^{23}$ Columns (4), (7-A), and (8-B) will be discussed in the multinational section.
} 
An additional interesting marginal effect from the probit framework is the effect of being an exporter on outsourcing behavior. For both firms and plants in restricted and unrestricted cases, we see that being an exporter increases the probability of an organization's also being an outsourcer. The general range for this effect is between 17 percent and 28 percent. The high correlation between outsourcing and exporting activity is important not only for its own sake but also because it supports the idea that when researching outsourcing, one should account for export status and that, conversely, when researching exporting, one should account for outsourcing status.

Higher productivity is a factor in the determination of an organization's outsourcing behavior. For both firms and plants, the probit results are consistent with Antràs and Helpman's theory (2004) that organizations can be sorted into outsourcing and non-outsourcing forms on the basis of productivity levels.

\section{Productivity Change Regressions}

Does outsourcing status contain information regarding the growth in productivity of establishments and firms? The results of equation (7) are presented for plants and firms (table 10). As in table 9, different specifications test the restricted and unrestricted samples. The specifications range from the parsimonious (columns 1, 5-A, and 7-B)-to a specification controlling for size, exporting status, skill composition, multi-unit status, industry, time, and location (4, 6-A, and 8-B).

For plants, the full, unrestricted sample of all industries and the restricted cases offer little evidence of higher mean rates of growth in productivity for establishments defined as outsourcers. Table 10 shows that only two of the specifications contain statistically significant coefficients on the outsourcing indicator. In addition, the significance and signs of the exporting dummy for plants are similar to the results presented in Bernard and Jensen (1999, 2004a).

The firm-level productivity change regressions in table 10, however, display interesting results for the coefficients on outsourcing. For each specification, and in both the unrestricted and the restricted cases, we see significantly higher rates of productivity growth for outsourcers. These results range from 0.53 percent to 1.5 percent higher growth in log productivity for all industries. The restricted-A case is similar, exhibiting a premium that ranges from 0.89 percent to 1.46 percent for log productivity growth, while the restricted-B regressions find 0.76 percent to 1.48 percent higher growth rates for outsourcing firms. 


\section{Firm-Level Rationalization}

What might explain the existence of outsourcing firms' productivity growth and the absence of any significant growth differential between outsourcing and non-outsourcing plants? At the industry level, a significant portion of productivity growth results from rationalization-the exit of inefficient plants and the reallocation of resources to more-efficient organizations. ${ }^{24} \mathrm{~A}$ similar rationalization may hold at the firm level — a firm that chooses to import from abroad increases its average productivity through specializing and through reallocating resources to the more productive parts of the production process. This story would lead us to expect higher average productivity growth for outsourcing firms, holding alternative determinants of productivity growth constant.

I perform two basic tests of the rationalization hypothesis. The first test estimates the relation between firm-level productivity growth and changes in the number of plants within a firm. The second test estimates the difference between outsourcing and non-outsourcing organizations in the growth of the number of plants per firm. The first specification is

$$
\Delta \ln \left(\operatorname{prod}_{t}\right)=\alpha_{1}+\alpha_{2} \Delta \text { Plants }_{t}+X_{t} \beta+\varepsilon_{t},
$$

and the second is

$$
\Delta \text { Plants }_{t}=\beta_{1}+\beta_{2} P S_{t}+X_{t} \phi+v_{t},
$$

where $X_{t}$ is a vector of controls, including size, time, industry, and location. Given the rationalization hypothesis, we should expect that $\alpha_{2}$ and $\beta_{2}$ are both negative and significant. Although further, more expansive analysis of this hypothesis is left for future work, the coefficient estimates for $\alpha_{2}$ and $\beta_{2}$ are telling. Both are significant at the 1 percent level:

$\alpha_{2}=-0.0355, \beta_{2}=-0.0063$, and the standard errors for $\alpha_{2}$ and $\beta_{2}$ are 0.0123 and 0.0015 respectively.

\section{Multinational Status}

The previous tests find that plants and firms are more likely to outsource the larger their productivity, that outsourcing plants and firms have a premium on characteristics, except for wages, and that firms, not plants, tend to have larger productivity growth over time. A question remains with respect to these results: Is the activity of outsourcing the primary cause for such empirical findings, or alternatively, are the results driven by a possible omitted variable correlated 
with the outsourcing proxy? The omitted variable that should most cause concern is the multinational status of plants and firms, particularly in the cases in which the results in the multinational literature mirror the outsourcing results presented earlier.

Neither the CMF nor the ASM collects information regarding plants' multinational status, but the LCSs of 1987 and 1992, used by Doms and Jensen (1998a, 1998b) and Bernard and Jensen (2005), allow for the creation of an indicator of domestic multinational status. ${ }^{25}$ The LCS is merged with the panels of estimated productivity, restricting the samples to only large U.S.owned firms. As in previous work, the indicator for multinational status is

$$
\begin{aligned}
& \text { USMNC }= 1 \text { if } \frac{\text { Foreign Assets }}{\text { Total Assets }} \geq 0.10 \\
& 0 \quad \text { otherwise }
\end{aligned} .
$$

A comparison of the pre- and post-merger versions of the 1987 sample indicates how the merger affects sample size. The merger decreases the sample of plants from about 25,000 to 15,000 , while it reduces the sample of firms from 15,000 to 4,000 . The correlation between the outsourcing indicator and multinational status is 10 percent for plants and 16 percent for firms. ${ }^{26}$

The merged data excludes foreign-owned plants and firms. This omission is not a significant drawback, as the new sample allows the analysis to control for multinational status while identifying the importance of outsourcing through the variation between outsourcers and non-outsourcers. The tests in this section mirror those employed earlier, but they now include a dummy variable indicating multinational status.

\section{Results of the Inclusion of Multinational Status}

The low correlation between multinational status and outsourcing status predicts that the earlier results' significance should not change qualitatively when controlling for multinational status. This prediction is exactly what occurs in the characteristics regressions and in the probit specifications. The regression results for dynamic productivity change are different, but I will argue that the change results from sample differences, not from the added control within the regressions.

\footnotetext{
${ }^{24}$ Rationalization is defined by Head and Ries (1999) as a decline in the number of plants accompanied by increases in the output per plant.

${ }^{25} \mathrm{BEA}$ data, which are not available for this project, allow for the creation of an indicator of foreign multinational status.

${ }^{26}$ The correlation between the multinational indicator and export status is 20 percent. This value is identical to that provided by Bernard and Jensen (2004a).
} 
I begin by presenting the controlled specifications of the characteristics regressions based on equation (8) (table 11). The results are strikingly similar quantitatively and in significance to the results found in table 8 . The multinational indicator is also significant except in three specifications.

The probit analysis including the multinational indicator is presented in table 9, columns 4, 7-A, and 8-B. Again, there is no noteworthy change in the quantitative results, qualitative results, or significance of the regressions.

Next, I present the results of the dynamic specifications with the inclusion of the multinational control (table 12). ${ }^{27}$ Table 12 includes similar specifications to columns 4, 6-A, and 8-B from table 10. These specifications are identical to the previous regressions without the multinational control but are run on the smaller sample of the merged multinational data, whereas 4-MN, 6-A-MN, and 8-B-MN include the multinational control.

Unlike the earlier results for firms' productivity growth, the results here do not show a significant difference between the growth rates of log productivity over time. One possible cause for this departure from the earlier results might arise from the smaller sample that results from merging the ASM and the LCS. The fact that the outsourcing coefficients are almost the same for each case in table 12 presents evidence for this hypothesis.

To test this hypothesis, all three cases are tested for the difference in the outsourcing coefficient between the specifications with and without the multinational control. I draw 1,000 bootstrap samples for each test and report the $\chi^{2}$-values in the lower portion of table 7 . On the basis of the results, I cannot reject the hypothesis that the two coefficients are the same for all three cases, an indication that my previous results are robust to the addition of a multinational control.

\section{CONCLUSION}

More empirical research on outsourcing will better inform participants in today's vigorous outsourcing debate. This paper uses confidential microdata from the Longitudinal Research Database to address the differences in characteristics between outsourcers and non-outsourcers and the productivity-related implications of outsourcing. The measure of outsourcing comes from a question asked in the 1987 and 1992 Census of Manufactures regarding a respondent

\footnotetext{
${ }^{27}$ The results are reported only for firms because the earlier plant-level results were insignificant.
} 
plant's foreign purchases of intermediate materials. One drawback of this measure of outsourcing is that it may include purchases of raw materials. To alleviate this problem and more precisely identify plants that outsource, I test the hypotheses on two restricted subsets of industries. The restricted samples include industries less disposed to purchase raw materials and more prone to engage in outsourcing. The results hold for the restricted and unrestricted samples and are robust to alternative specifications.

This paper contains several key results. First, outsourcers are "outstanding" in that, compared with non-outsourcers, there are premia for outsourcers over non-outsourcing organizations for a variety of plant and firm characteristics. In other words, outsourcing plants and firms have significantly higher employment, shipments, value added, capital, investment, and skilled-worker fractions, even when controlling for various plant and firm characteristics. One exception to this outsourcing premia is that wages tend to be the same for both outsourcers and non-outsourcers. The absence of higher wages for outsourcing plants and firms contrasts with the wage premia in the "exceptional" exporting literature.

Second, organizations that outsource have higher total factor productivity. In addition to comparing the average productivity of outsourcing organizations with that of non-outsourcing organizations, I estimate a probit of the probability of outsourcing dependent upon productivity. This specification is consistent with the theory that assumes that productivity is exogenous when choosing an outsourcing or non-outsourcing organizational form. An increase in productivity of 1 standard deviation raises the probability of outsourcing 1.61 to 2 percentage points for plants and 1.7 to 3.2 percentage points for firms.

Finally, given controls similar to those in the previous specifications, firm-level productivity growth is significantly higher for outsourcers, a result that does not hold at the plant level. An outsourcing firm's productivity growth is 0.53 to 1.50 percent higher per year than that of a non-outsourcing firm.

It is important to address the above-mentioned results in the context of the outsourcing debate. Outsourcers are an "outstanding” group of organizations along a variety of dimensions. One exception, as noted previously, is that outsourcing firms and plants do not appear to pay employees any more than do non-outsourcing organizations. But, paying the same as the average firm is not a reason to hinder a production process that is becoming more prevalent among today's manufacturing organizations.

If outsourcing organizations were marginal and needed to decrease intermediate input 
costs to survive, the implications would be much different for policymakers. Because the results point toward outsourcers being "outstanding," anti-outsourcing legislation will affect the larger, more productive, and internationally competitive organizations. Thus, states that restrict outsourcing may drive away the largest and most productive organizations.

Much future work is warranted to complete our understanding of outsourcing. This paper does not delve deeply enough into the question of why firms may choose an outsourcing organizational form. To help answer this question, future research needs to explore industry and geographic variation. Although I did not report the values, the controls for industry and location are significant for certain four-digit industries and for particular states. Exploiting the detailed industry, product, and location information contained in the LRD may allow for the behavior of outsourcing organizations to be further analyzed. 


\section{Appendix: Capital Construction}

I construct real capital stock from 1987 to 1996 using the LRD from 1982 to 1996. The LRD contains information on buildings and machinery, so each stock is calculated separately and then added together in order to arrive at the total capital stock for a given plant. Three steps are followed in order to arrive at the real capital stock utilized in the productivity estimations. First, investment in calculated for plants over the time span of the data. Second, starting values of capital are found. Third, the perpetual inventory method is implemented over the entire panel.

Investment is deflated using price indices from the NBER Productivity Database ${ }^{28}$. The LRD contains yearly values for investment for both used and new machinery and used and new building purchases. Used and new purchases are summed up and deflated for each year for both machinery and buildings.

Once investment values are arrived at the entire span of data for each plant is searched for appropriate capital starting values using the total value of buildings and machinery at the beginning of the year. Total capital stock within the LRD, for buildings and machinery ( $B A B$ and $M A B)$, exists only during certain years within the dataset. The first year that these values are non-empty will provide the end of year capital levels for the previous year. Depending on where starting capital falls within in the series of years a plant exists, the capital stock perpetual inventory method iterates forward, backward, or both, in order to create the entire series of capital stock.

Specifically, $K_{t+1}^{j}=\left(1-\delta^{j}\right) K_{t}^{j}+i_{t+1}^{j}$, where $K_{t+1}$ is the capital stock at the end of the

year and $i_{t+1}$ is investment during the year, and $j$ is either buildings or machinery. Depreciation is 5 percent and 10 percent for buildings and machinery, respectively. When $M A B$ and $B A B$ exist in the year in which a plant enters the dataset, or when the dataset starts, our initial capital stock for that year $t$ is, for the case of capital machinery, $K_{t}^{\text {mach }}=\left(1-\delta^{\text {mach }}\right) M A B_{t}+i_{t}^{\text {mach }}$.

\footnotetext{
${ }^{28}$ See Bartelsman, Becker, and Gray (2000).
} 


\section{References}

Abraham, Katherine G. and Susan K. Taylor, 1996. Firms Use of Outside Contractors: Theory and Evidence. Journal of Labor Economics 14, 394-424.

Antràs, Pol and Elhanan Helpman, 2004. Global Sourcing. Journal of Political Economy 112, 552580.

Bernard, Andrew B. and Bradford Jensen, 1995. Exporters, Jobs, and Wages in U.S. Manufacturing: 1976-1987. Brookings Papers on Economic Activity: Microeconomics 1995, 67-112.

Bernard, Andrew B. and Bradford Jensen, 1999. Exceptional Exporter Performance: Cause, Effect, or Both? Journal of International Economics 47, 1-25.

Bernard, Andrew B. and Bradford Jensen, 2004a. Exporting and Productivity in the US. Oxford Review Oxford Review of Economic Policy 20, 343-357.

Bernard, Andrew B. and Bradford Jensen, 2004b. Why Some Firms Export. The Review of Economics and Statistics 86, 561-569.

Bernard, Andrew B. and Bradford Jensen, 2005. Firm Structure, Multinationals, and Manufacturing Plant Deaths. Mimeo, Dartmouth.

Campa, Jose and Linda S. Goldberg, 1997. The Evolving External Orientation of Manufacturing: A Profile of Four Countries. FRBNY Economic Policy Review, 53-81.

Doms, M. and Timothy Dunne, 1998. Capital Adjustment Patterns in Manufacturing Plants. Review of Economic Dynamics 1, 409-429.

Doms, M. and Bradford Jensen, 1998. Comparing Wages, Skills, and Productivity Between Domestic and Foreign Owned Manufacturing Establishments, in: Baldwin, R., Lipsey, R. Richardson, D.J. (Eds.) The United States, Geography vs. Ownership in Economic Accounting. University of Chicago Press, Chicago, pp. 235-255.

Doms, M. and Bradford Jensen, 1998b. Productivity, Skill, and Wage Effects of Multinational 
Corporations in the U.S., in: Woodward, D. and Douglas Nigh (Eds.) Multinational Corporations in the United States, Foreign Ownership and the Consequences of Direct Investment in the United States. Quorum Books, Westport, pp. 49-68.

Ethier, Wilfred, 1982. National and International Returns to Scale in the Modern Theory for International Trade. American Economic Review 72, 389-405.

Feenstra, Robert C., 1998. Integration of Trade and Disintegration of Production in the Global Economy, Journal of Economic Perspectives 12, 31-50.

Feenstra, Robert C. and Gordon Hanson, 1996. Globalization, Outsourcing, and Wage Inequality, Papers and Proceedings of the 108th Annual Meeting of the American Economic Review, 240-245. Feenstra, R.C. and G. Hanson, 1999. The Impact of Outsourcing and High-Technology Capital on Wages: Estimates for the U.S., 1972-1990. Quarterly Journal of Economics 114, 907-940.

Feenstra, R. C. and G. Hanson, 2002. Global Production and Inequality: A Survey of Trade and Wages, in: E.K. Choi and J. Harrigan (Eds.), Handbook of International Trade, Blackwell, Ames. Feenstra, Robert C, James R. Markusen, and William Zeile, 1992. Accounting for Growth in New Inputs: Theory and Evidence. American Economic Review 82, 415-421.

Feenstra, Robert C, 2002. Input Variety and Total Factor Productivity in General Equilibrium. Working Paper, UC Davis.

Girma, Sourafel and Holger Görg, 2004. Outsourcing, Foreign Ownership, and Productivity: Evidence from UK Establishment-Level Data. Review of International Economics 12, 817-832. Görg, Holger, Aoife Hanley and Eric Strobl, 2004. Outsourcing, Foreign Ownership, Exporting, and Productivity: An Empirical Investigation with Plant-Level Data. Working Paper, U Nottingham. Grossman, Gene M. and Elhanan Helpman, 2005. Outsourcing in a Global Economy. Review of Economic Studies 72, 135-150.

Grossman, Gene M. and Elhanan Helpman, 2002. Outsourcing versus FDI in Industry Equilibrium, 
NBER working paper 9300.

Hanson, Gordon H., Raymond J. Mataloni Jr., and Matthew J. Slaughter, 2003. Vertical Production

Networks in Multinational Firms. Review of Economics and Statistics (forthcoming).

Halvorsen, R. and R. Palmquist, 1980. The Interpretation of Dummy Variables in Semi logarithmic Equations. American Economic Review 70, 474-5.

Head, Keith and John Ries, 1992. Rationalization effects of tariff reductions. Journal of International Economics 47, 295-320.

Hummles, David, Jun Ishii, and Kei-Mu Yi, 2001. The Nature and Growth of Vertical Specialization in World Trade, Journal of International Economics 54, 75-86.

Krugman, Paul, 1995. Growing World Trade: Causes and Consequences. Brooking Paper on

Economic Activity 1, 327-362.

Levinsohn, James, and Amil Petrin, 2003. Estimating Production Functions Using Inputs to Control for Unobservables. Review of Economic Studies 7, 317-341.

Melitz, Marc, 2003. The Impact of Trade on Intra-Industry Reallocations and Aggregate Industry Productivity. Econometrica 71, 1695-1725.

Olley, S. and Ariel Pakes, 1996. The Dynamics of Productivity in the Telecommunications Equipment Industry. Econometrica 64, 1263-1298.

Senses, M., 2005. The Effects of Outsourcing on the Elasticity Of Labor Demand. Mimeo, SAIS. Yeats, A.J., 2001. Just How Big Is Global Production Sharing? in: Arndt, S. and H. Kierzkowski (Eds.), Fragmentation: New Production Patterns in the World Economy. Oxford University Press, Oxford, pp. 108-43. 
Table 1: Two Digit Standard Industrial Classification Codes and Definition of the Restricted-A Measure ${ }^{1}$

\begin{tabular}{|c|c|c|}
\hline Code & Rest.-A Measure & US SIC Description \\
\hline 20 & 0 & Food and kindred products \\
\hline 21 & 0 & Tobacco manufactures \\
\hline 22 & 0 & Textile mill products \\
\hline 23 & 1 & Apparel and other textile products \\
\hline 24 & 0 & Lumber and wood products \\
\hline 25 & 0 & Furniture and fixtures \\
\hline 26 & 1 & Paper and allied products \\
\hline 27 & 1 & Printing and publishing \\
\hline 28 & 0 & Chemicals and allied products \\
\hline 29 & 0 & Petroleum and coal products \\
\hline 30 & 0 & Rubber and miscellaneous plastics products \\
\hline 31 & 1 & Leather and leather products \\
\hline 32 & 0 & Stone, clay, glass, and concrete products \\
\hline 33 & 1 & Primary metal industries \\
\hline 34 & 0 & Fabricated metal products \\
\hline 35 & 1 & Industrial machinery and equipment \\
\hline 36 & 1 & Electrical and electronic equipment \\
\hline 37 & 1 & Transportation equipment \\
\hline 38 & 1 & Instruments and related products \\
\hline 39 & 1 & Miscellaneous manufacturing industries \\
\hline
\end{tabular}

1. Restricted measure eliminates manufacturing sectors that are not known as outsourcing industries while removing industries that purchase significant amounts of raw materials. 
Table 2: Outsourcing Establishments for 1987 and 1992

\begin{tabular}{|c|c|c|c|}
\hline 1987 & $\begin{array}{l}\text { Fraction of Foreign } \\
\text { Content }=0\end{array}$ & $\begin{array}{l}\text { Fraction of Foreign } \\
\text { Content }>0\end{array}$ & Total \\
\hline Non-Outsourcing & 24,328 & 0 & 24,328 \\
\hline Outsourcing & 404 & 9,917 & 10,321 \\
\hline Total & 24,732 & 9,917 & 34,649 \\
\hline 1992 & $\begin{array}{l}\text { Fraction of Foreign } \\
\text { Content }=0\end{array}$ & $\begin{array}{c}\text { Fraction of Foreign } \\
\text { Content }>0\end{array}$ & Total \\
\hline Non-Outsourcing & 30,156 & 0 & 30,156 \\
\hline Outsourcing & 569 & 8,854 & 9,423 \\
\hline Total & 30,725 & 8,854 & 39,579 \\
\hline
\end{tabular}

Table 3: Composition of Pooled Data from 1987 and 1992

\begin{tabular}{ccccc}
\hline & Outsourcers & Exporters & $\begin{array}{c}\text { Outsource \& } \\
\text { Exporters }\end{array}$ & Neither \\
\hline $\begin{array}{c}\text { Fraction of } \\
\text { Plants }\end{array}$ & 0.27 & 0.41 & 0.18 & 0.5 \\
$\begin{array}{c}\text { Fraction of } \\
\text { Output }\end{array}$ & 0.54 & 0.64 & 0.41 & 0.23 \\
\hline
\end{tabular}


Table 4: Descriptive Statistics for 1987

\begin{tabular}{|c|c|c|c|c|c|c|c|c|}
\hline SIC & Total Plants & $\begin{array}{c}\text { Fraction of } \\
\text { Outsourcing Plants } \\
\end{array}$ & $\begin{array}{c}\text { Fraction of Parts and } \\
\text { Materials } \\
\text { Outsourced } \\
\end{array}$ & $\begin{array}{c}\text { Foreign Content } \\
\text { Percent of Total } \\
\text { Inputs } \\
\end{array}$ & $\begin{array}{c}\text { Total Emp if } \\
\text { Outsource }\end{array}$ & $\begin{array}{c}\text { Total Emp if not } \\
\text { Outsource }\end{array}$ & $\begin{array}{c}\text { Gross Output if } \\
\text { Outsource } \\
\end{array}$ & $\begin{array}{c}\text { Gross Output if not } \\
\text { Outsource }\end{array}$ \\
\hline 20 & 4375 & 16 & 18.63 & 2.40 & 288.79 & 185.98 & 86442.7 & 43435.51 \\
\hline 21 & 45 & 55.56 & 20.88 & 8.61 & 1326.6 & 186.7 & 647681.2 & 52106.6 \\
\hline 22 & 1161 & 21.71 & 17.23 & 2.43 & 350.16 & 349.22 & 39916.06 & 33411.65 \\
\hline 23 & 1600 & 23.62 & 23.61 & 3.36 & 281.75 & 206.92 & 27352.42 & 13127.12 \\
\hline 24 & 1686 & 14.89 & 15.53 & 1.68 & 186.22 & 119.78 & 23602.08 & 15942.25 \\
\hline 25 & 817 & 35.99 & 12.03 & 2.73 & 358.16 & 226.77 & 30876.7 & 16655.1 \\
\hline 26 & 1795 & 18.89 & 12.24 & 1.63 & 376.64 & 183.6 & 80424.23 & 35854.42 \\
\hline 27 & 2399 & 19.72 & 44.61 & 3.89 & 413.72 & 183.11 & 44600.51 & 21667.19 \\
\hline 28 & 2471 & 36.54 & 15.17 & 3.93 & 309.1 & 138.61 & 96095.47 & 43073.64 \\
\hline 29 & 533 & 21.39 & 35.41 & 6.74 & 411.32 & 77.02 & 648590.5 & 75078.01 \\
\hline 30 & 1646 & 25.03 & 11.65 & 1.86 & 344 & 161.11 & 42274.27 & 18918.21 \\
\hline 31 & 344 & 42.44 & 23.18 & 6.60 & 253.9 & 198.51 & 20196.9 & 14239.33 \\
\hline 32 & 1460 & 23.29 & 20.45 & 3.18 & 205.07 & 115.54 & 27525.48 & 15364.64 \\
\hline 33 & 1341 & 34.68 & 21.31 & 5.35 & 484.4 & 265.49 & 99821.51 & 47244.21 \\
\hline 34 & 3677 & 32.85 & 18.03 & 3.61 & 239.03 & 144.48 & 29374.5 & 16439.97 \\
\hline 35 & 3808 & 38.87 & 13.93 & 3.24 & 400.3 & 134.69 & 63989.45 & 15154.1 \\
\hline 36 & 2355 & 46.16 & 15.32 & 4.16 & 525.13 & 311.13 & 69292.83 & 35469.21 \\
\hline 37 & 1308 & 42.81 & 12.31 & 3.39 & 1555.7 & 558.71 & 311744.2 & 71401.91 \\
\hline 38 & 1166 & 51.11 & 13.55 & 3.91 & 601.31 & 442.96 & 77943.13 & 45612.48 \\
\hline 39 & 662 & 45.02 & 24.54 & 7.16 & 233.06 & 158.14 & 26486.88 & 16307.72 \\
\hline Total & 34649 & 29.79 & 19.48 & 3.99 & 457.22 & 217.42 & 124711.55 & 32325.16 \\
\hline
\end{tabular}


Table 5: Descriptive Statistics for 1992

\begin{tabular}{|c|c|c|c|c|c|c|c|c|}
\hline SIC & Total Plants & $\begin{array}{c}\text { Fraction of } \\
\text { Outsourcing Plants }\end{array}$ & $\begin{array}{c}\text { Fraction of Parts and } \\
\text { Materials } \\
\text { Outsourced } \\
\end{array}$ & $\begin{array}{c}\text { Foreign Content } \\
\text { Percent of Total } \\
\text { Inputs } \\
\end{array}$ & $\begin{array}{c}\text { Total Emp if } \\
\text { Outsource }\end{array}$ & $\begin{array}{c}\text { Total Emp if not } \\
\text { Outsource } \\
\end{array}$ & $\begin{array}{c}\text { Gross Output if } \\
\text { Outsource }\end{array}$ & $\begin{array}{c}\text { Gross Output if not } \\
\text { Outsource }\end{array}$ \\
\hline 20 & 4049 & 15.88 & 21.37 & 2.42 & 250.01 & 207.4 & 93607.49 & 60075.9 \\
\hline 21 & 40 & 57.5 & 21.23 & 9.23 & 1250.217 & 250.7 & 1380385 & 105768.4 \\
\hline 22 & 920 & 22.83 & 17.16 & 2.24 & 387.3714 & 301.09 & 48939.37 & 35918.46 \\
\hline 23 & 1657 & 19.92 & 24.92 & 2.40 & 231.66 & 165.26 & 31082.52 & 12858.69 \\
\hline 24 & 2656 & 9.07 & 18.39 & 1.00 & 154.41 & 76.08 & 23341.16 & 12656.94 \\
\hline 25 & 1015 & 27.39 & 15.63 & 2.56 & 301.08 & 162.43 & 33503.89 & 15454.19 \\
\hline 26 & 1908 & 15.46 & 13.5 & 1.30 & 368.92 & 178.22 & 100289 & 39867.35 \\
\hline 27 & 3696 & 10.77 & 35.36 & 1.45 & 327.3 & 129.89 & 41535.69 & 18384.25 \\
\hline 28 & 2586 & 31.86 & 17.92 & 3.64 & 311.4 & 127.63 & 140405.9 & 50372.71 \\
\hline 29 & 681 & 17.77 & 39.65 & 6.29 & 506.91 & 50.07 & 946103.5 & 46894.91 \\
\hline 30 & 2692 & 22.03 & 14.09 & 1.79 & 268.67 & 119.16 & 40798.59 & 15881.2 \\
\hline 31 & 180 & 48.89 & 20.7 & 5.90 & 258.91 & 193.26 & 27578.51 & 18915.04 \\
\hline 32 & 2487 & 13.35 & 20.78 & 1.46 & 196.17 & 66.47 & 29220.85 & 9571.923 \\
\hline 33 & 1400 & 28.5 & 22.9 & 4.21 & 375.39 & 220.29 & 105580.8 & 42985.84 \\
\hline 34 & 3906 & 23.43 & 18.65 & 2.25 & 211.69 & 114.83 & 32156.39 & 16076.68 \\
\hline 35 & 4140 & 30.48 & 17.13 & 2.79 & 367.95 & 97 & 74050.4 & 14085.73 \\
\hline 36 & 2135 & 46.51 & 19.31 & 4.70 & 437.69 & 275.09 & 77369.03 & 43296.09 \\
\hline 37 & 1432 & 41.06 & 13.8 & 3.41 & 1195.81 & 439.08 & 321984.7 & 69724.52 \\
\hline 38 & 1188 & 48.32 & 14.51 & 3.12 & 470.47 & 298.7 & 84757 & 40502.39 \\
\hline 39 & 811 & 38.96 & 20 & 4.26 & 222.91 & 93.38 & 31570.4 & 12322.88 \\
\hline Total & 39579 & 23.81 & 20.35 & 3.32 & 404.75 & 178.30 & 183213.01 & 34080.70 \\
\hline
\end{tabular}


Table 6: Plant Characteristics, 1987

\begin{tabular}{|c|c|c|c|c|}
\hline \multirow[t]{2}{*}{ Characteristic } & \multicolumn{2}{|c|}{ Outsourcing } & \multicolumn{2}{|c|}{ Non-outsourcing } \\
\hline & $\underline{\text { Mean }}$ & $\underline{\text { S.D. }}$ & $\underline{\text { Mean }}$ & $\underline{\text { S.D. }}$ \\
\hline Total employment (number) & 436.46 & 1155.64 & 202.88 & 489.07 \\
\hline Total value of shipments & $81,488,920$ & $266,176,500$ & $30,619,600$ & $87,801,730$ \\
\hline Wage per worker & 25,062 & 8,301 & 23,292 & 8,543 \\
\hline Wage per production worker & 21,551 & 8,228 & 20,445 & 9,159 \\
\hline Wage per non-production worker & 34,145 & 14,727 & 32,809 & 17,300 \\
\hline Shipments per worker & 180,784 & 244,995 & 178,101 & 276,725 \\
\hline Value added per worker & 80,653 & 102,224 & 75,186 & 123,475 \\
\hline Capital per worker & 62,101 & 118,757 & 60,657 & 171,040 \\
\hline Investment per worker & 5,240 & 16,765 & 4,597 & 11,845 \\
\hline $\begin{array}{l}\text { Fraction of nonproduction workers } \\
\text { in employment }\end{array}$ & $32.2 \%$ & $19.5 \%$ & $28.8 \%$ & $20.2 \%$ \\
\hline
\end{tabular}
Note: Monetary values are in 1987 dollars except as noted.

Table 7: Firm Characteristics, 1987

\begin{tabular}{lrrrr}
\hline Characteristic & \multicolumn{2}{c}{ Outsourcing } & \multicolumn{2}{c}{ Non-outsourcing } \\
\hline Mean & $\underline{\text { S.D. }}$ & $\underline{\text { Mean }}$ & $\underline{\text { S.D. }}$ \\
Total employment (number) & 1387.63 & 7765.34 & 188.18 & 482.11 \\
Total value of shipments & $248,925,000$ & $1,677,846,000$ & $23,858,000$ & $89,037,470$ \\
Wage per worker & 23,884 & 7,805 & 22,843 & 8,985 \\
Wage per production worker & 19,797 & 7,207 & 19,297 & 10,250 \\
Wage per non-production worker & 34,423 & 14,931 & 34,470 & 20,591 \\
Shipments per worker & 146,228 & 194,564 & 122,412 & 165,263 \\
Value added per worker & 65,382 & 74,167 & 54,493 & 75,040 \\
Capital per worker & 44,164 & 74,118 & 36,932 & 72,123 \\
Investment per worker & 3,923 & 7,124 & 3,293 & 6,999 \\
Fraction of nonproduction workers & & & & \\
in employment & $32.3 \%$ & $18.5 \%$ & $29.4 \%$ & $19.6 \%$ \\
\hline
\end{tabular}


Table 8: Pooled OLS Regression of Characteristics on Outsourcing Status

\begin{tabular}{|c|c|c|c|c|}
\hline Characteristic & $\begin{array}{r}\text { Outsourcing } \\
\text { Dummy } \\
\end{array}$ & $\begin{array}{r}\text { Exporting } \\
\text { Dummy } \\
\end{array}$ & $R^{2}$ & $N$ \\
\hline \multicolumn{5}{|c|}{ Plants } \\
\hline Total employment & $\begin{array}{l}0.38185 \text { *** } \\
(0.01383)\end{array}$ & $\begin{array}{l}0.58364 \\
(0.01027)\end{array}$ & 0.446 & 69,836 \\
\hline Total value of shipments & $\begin{array}{l}0.50620 * * * \\
(0.01162)\end{array}$ & $\begin{array}{l}0.67975 * * * \\
(0.01148)\end{array}$ & 0.489 & 69,830 \\
\hline Wage per worker & $\begin{array}{l}0.02287 \\
(0.00282)\end{array}$ & $\begin{array}{l}0.06495 \text { *** } \\
(0.00290)\end{array}$ & 0.408 & 69,825 \\
\hline Wage per production worker & $\begin{array}{r}0.00267 \\
(0.00310)\end{array}$ & $\begin{array}{l}0.04511 * * * \\
(0.00315)\end{array}$ & 0.397 & 68,833 \\
\hline Wage per non-production worker & $\begin{array}{l}0.02360 \text { *** } \\
(0.00386)\end{array}$ & $\begin{array}{l}0.03870 \text { ***} \\
(0.00414)\end{array}$ & 0.152 & 69,700 \\
\hline Shipments per worker & $\begin{array}{l}0.13595 \text { *** } \\
(0.00602)\end{array}$ & $\begin{array}{l}0.11417^{\star \star \star} \\
(0.00612)\end{array}$ & 0.488 & 69,830 \\
\hline Value added per worker & $\begin{array}{l}0.06910 * * * \\
(0.00681)\end{array}$ & $\begin{array}{l}0.14353 * * * \\
(0.00697)\end{array}$ & 0.273 & 69,836 \\
\hline Capital per worker & $\begin{array}{l}0.07922 \text { *** } \\
(0.00851)\end{array}$ & $\begin{array}{l}0.12870 * \star * \\
(0.00880)\end{array}$ & 0.450 & 69,836 \\
\hline Investment per worker & $\begin{array}{l}0.09399 * * * \\
(0.01261)\end{array}$ & $\begin{array}{l}0.09838 * * * \\
(0.01309)\end{array}$ & 0.227 & 62,270 \\
\hline $\begin{array}{l}\text { Nonproduction workers in total } \\
\text { employment }\end{array}$ & $\begin{array}{l}0.01839 \text { *** } \\
(0.00162)\end{array}$ & $\begin{array}{l}0.03286 \text { *** } \\
(0.00160)\end{array}$ & 0.386 & 69,836 \\
\hline \multicolumn{5}{|c|}{ Firms } \\
\hline Total employment & $\begin{array}{l}0.59582 \text { *** } \\
(0.01586)\end{array}$ & $\begin{array}{l}0.76194^{* \star *} \\
(0.01531)\end{array}$ & 0.497 & 34,645 \\
\hline Total value of shipments & $\begin{array}{l}0.75404 * * * \\
(0.01758)\end{array}$ & $\begin{array}{l}0.88511 \\
(0.01693)\end{array}$ & 0.541 & 34,643 \\
\hline Wage per worker & $\begin{array}{l}0.02148 \text { *** } \\
(0.00425)\end{array}$ & $\begin{array}{l}0.06815 \text { *** } \\
(0.00440)\end{array}$ & 0.355 & 34,643 \\
\hline Wage per production worker & $\begin{array}{r}0.00335 \\
(0.00449)\end{array}$ & $\begin{array}{l}0.04222 \text { *** } \\
(0.00460)\end{array}$ & 0.327 & 34,238 \\
\hline Wage per non-production worker & $\begin{array}{r}0.00730 \\
(0.00595)\end{array}$ & $\begin{array}{l}0.05251 * * \star \\
(0.00651)\end{array}$ & 0.136 & 34,559 \\
\hline Shipments per worker & $\begin{array}{l}0.15590 \text { *** } \\
(0.00774)\end{array}$ & $\begin{array}{l}0.12023 \text { *** } \\
(0.00779)\end{array}$ & 0.420 & 34,643 \\
\hline Value added per worker & $\begin{array}{l}0.08621 \text { *** } \\
(0.00831)\end{array}$ & $\begin{array}{l}0.13339 * * * \\
(0.00831)\end{array}$ & 0.246 & 34,645 \\
\hline Capital per worker & $\begin{array}{l}0.09809 * * \star \\
(0.01195)\end{array}$ & $\begin{array}{l}0.13399 * \star \star \\
(0.01226)\end{array}$ & 0.389 & 34,645 \\
\hline Investment per worker & $\begin{array}{l}0.10924 * * * \\
(0.01770)\end{array}$ & $\begin{array}{l}0.10543 * * * \\
(0.01869)\end{array}$ & 0.214 & 29,908 \\
\hline $\begin{array}{l}\text { Nonproduction workers in total } \\
\text { employment }\end{array}$ & $\begin{array}{l}0.02046 \text { *** } \\
(0.00226)\end{array}$ & $\begin{array}{l}0.03278 \text { *** } \\
(0.00227)\end{array}$ & 0.354 & 34,645 \\
\hline
\end{tabular}

Note: Coefficients from a pooled regression on outsourcing dummy. Each regression includes a time dummy, Huber-White consistent standard errors, and corrects for within-group dependence over time. ***, **, and * represent 1, 5, and 10\% significance respectively. Controls have been added for size (except for shipments and employment specifications), industry, state, and multi-unit status. 
Table 9: Probit Summary: Probability of Outsourcing-- dF/dx, 1987 and 1992

\begin{tabular}{|c|c|c|c|c|c|c|c|c|}
\hline & \multicolumn{4}{|c|}{ Plants } & \multicolumn{4}{|c|}{ Plants: Restricted cases } \\
\hline & $(1)$ & (2) & (3) & (4) & $(5-A)$ & $(6-B)$ & $(7-A)$ & $(8-B)$ \\
\hline Productivity & $\begin{array}{l}0.01506 * * * \\
(0.0028)\end{array}$ & $\begin{array}{l}0.01091 \text { *** } \\
(0.0028)\end{array}$ & $\begin{array}{l}0.01067 * * * \\
(0.0028)\end{array}$ & $\begin{array}{l}0.01677^{* * *} \\
(0.0040)\end{array}$ & $\begin{array}{l}0.01199 * * * \\
(0.0044)\end{array}$ & $\begin{array}{l}0.01096 * \star * \\
(0.0033)\end{array}$ & $\begin{array}{l}0.01941 \text { *** } \\
(0.0064)\end{array}$ & $\begin{array}{l}0.01913 \text { *** } \\
(0.0047)\end{array}$ \\
\hline Exporter & & $\begin{array}{l}0.18597 * * * \\
(0.0047)\end{array}$ & $\begin{array}{l}0.17708 \text { *** } \\
(0.0047)\end{array}$ & $\begin{array}{l}0.16804 \\
(0.0064)\end{array}$ & $\begin{array}{l}0.21148 * * * \\
(0.0072)\end{array}$ & $\begin{array}{l}0.18851 \text { *** } \\
(0.0052)\end{array}$ & $\begin{array}{l}0.21094 \\
(0.0102)\end{array}$ & $\begin{array}{l}0.18002 \text { *** } \\
(0.0073)\end{array}$ \\
\hline Multinational & & & & $\begin{array}{l}0.01758 \text { *** } \\
(0.0062)\end{array}$ & & & $\begin{array}{l}0.03106 \text { *** } \\
(0.0099)\end{array}$ & $\begin{array}{l}0.01767 * * \\
(0.0072)\end{array}$ \\
\hline Size & & $x$ & $\mathrm{X}$ & $\mathrm{X}$ & $x$ & $\mathrm{x}$ & $x$ & $\mathrm{x}$ \\
\hline NP fraction & & & $x$ & $x$ & $\mathrm{X}$ & $x$ & $\mathrm{X}$ & $\mathrm{X}$ \\
\hline Multi-unit & & & $x$ & $x$ & $x$ & $\mathrm{x}$ & $x$ & $x$ \\
\hline$N$ & 59,569 & 59,569 & 59,569 & 34,106 & 28,686 & 48,813 & 16,003 & 27,092 \\
\hline \multirow[t]{2}{*}{ Log-Ihood } & $-29,194.0$ & $-27,996.1$ & $-27,881.8$ & $-16,953.9$ & $-14,242.6$ & $-23,785.2$ & $-8,548.2$ & $-14,145.1$ \\
\hline & \multicolumn{4}{|c|}{ Firms } & \multicolumn{4}{|c|}{ Firms: Restricted Cases } \\
\hline & $(1)$ & $(2)$ & (3) & $(4)$ & $(5-A)$ & $(6-B)$ & $(7-A)$ & $(8-B)$ \\
\hline Productivity & $\begin{array}{l}0.03699 * * * \\
(0.0045)\end{array}$ & $\begin{array}{l}0.02048 \text { *** } \\
(0.0047)\end{array}$ & $\begin{array}{l}0.01953 * * * \\
(0.0047)\end{array}$ & $\begin{array}{l}0.02679 * * * \\
(0.0131)\end{array}$ & $\begin{array}{l}0.03156 * * \star \\
(0.0069)\end{array}$ & $\begin{array}{l}0.02159 \text { *** } \\
(0.0053)\end{array}$ & $\begin{array}{l}0.01862 \\
(0.0162)\end{array}$ & $\begin{array}{l}0.02131 \\
(0.0143)\end{array}$ \\
\hline Exporter & & $\begin{array}{l}0.24238 * * * \\
(0.0065)\end{array}$ & $\begin{array}{l}0.22690 \text { *** } \\
(0.0065)\end{array}$ & $\begin{array}{l}0.28362 \text { *** } \\
(0.0172)\end{array}$ & $\begin{array}{l}0.24745 * * * \\
(0.0095)\end{array}$ & $\begin{array}{l}0.23401 \text { *** } \\
(0.0070)\end{array}$ & $\begin{array}{l}0.26982 \text { *** } \\
(0.0257)\end{array}$ & $\begin{array}{l}0.28199 \text { *** } \\
(0.0194)\end{array}$ \\
\hline Multinational & & & & $\begin{array}{l}0.06680 * \star \star \\
(0.0178)\end{array}$ & & & $\begin{array}{l}0.07449 \text { *** } \\
(0.0215)\end{array}$ & $\begin{array}{l}0.06965 \text { *** } \\
(0.0191)\end{array}$ \\
\hline Size & & $\mathrm{X}$ & $x$ & $X$ & $\mathrm{X}$ & $X$ & $\mathrm{X}$ & $\mathrm{X}$ \\
\hline NP fraction & & & $x$ & $x$ & 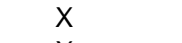 & $x$ & $x$ & $\mathrm{X}$ \\
\hline Multi-unit & & & $x$ & $\mathrm{X}$ & $x$ & $\mathrm{X}$ & $x$ & $x$ \\
\hline$N$ & 35,004 & 35,004 & 35,004 & 7,390 & 18,027 & 29,689 & 3,954 & 6,084 \\
\hline Log-Ihood & $-17,442.9$ & $-15,829.3$ & $-15,688.7$ & $-3,795.7$ & $-8,319.4$ & $-13,620.5$ & $-2,062.9$ & $-3,160.1$ \\
\hline
\end{tabular}

Note: Reported numbers are marginal effects from pooled probit regressions. In addition to industry and state controls, each regression includes a time dummy, Huber-White consistent standard errors, and corrects for within group dependence over time. ${ }^{* * *},{ }^{* *}$, and * represent 1,5 , and $10 \%$ significance respectively. 
Table 10: Plant and Firm Productivity Change Regressions

\begin{tabular}{|c|c|c|c|c|c|c|c|c|}
\hline & \multicolumn{4}{|c|}{ Plants } & \multicolumn{4}{|c|}{ Plants: Restricted Cases } \\
\hline & $(1)$ & $(2)$ & $(3)$ & $(4)$ & $(5-A)$ & $(6-A)$ & $(7-B)$ & $(8-B)$ \\
\hline Productivity & $\begin{array}{c}0.00293 \text { * } \\
(0.00162)\end{array}$ & $\begin{array}{r}0.00232 \\
(0.00175)\end{array}$ & $\begin{array}{r}0.00173 \\
(0.00199)\end{array}$ & $\begin{array}{r}0.00164 \\
(0.00200)\end{array}$ & $\begin{array}{l}0.00557 \\
(0.00236)\end{array}$ ** & $\begin{array}{r}0.00227 \\
(0.00305)\end{array}$ & $\begin{array}{r}0.00201 \\
(0.00176)\end{array}$ & $\begin{array}{l}0.000509 \\
(0.00218)\end{array}$ \\
\hline Exporter & & & $\begin{array}{l}-0.00705 \text { ** } \\
(0.00254)\end{array}$ & $\begin{array}{l}-0.00732 \text { ***} \\
(0.00255)\end{array}$ & & $\begin{array}{l}-0.01176 \text { *** } \\
(0.00392)\end{array}$ & & $\begin{array}{l}-0.008941 \text { *** } \\
(0.00275)\end{array}$ \\
\hline Size & & $\mathrm{x}$ & $x$ & $x$ & & $x$ & & $x$ \\
\hline NP fraction & & & $\mathrm{X}$ & $X$ & & $x$ & & $\mathrm{X}$ \\
\hline Multi-unit & & & & $x$ & & $x$ & & $x$ \\
\hline Industry & & & $x$ & $x$ & & $x$ & & $x$ \\
\hline Time & & & $x$ & $x$ & & $x$ & & $x$ \\
\hline State & & & & $\mathrm{X}$ & & $X$ & & $x$ \\
\hline$R^{2}$ & 0.000 & 0.000 & 0.011 & 0.011 & 0.000 & 0.013 & 0.000 & 0.013 \\
\hline \multirow[t]{2}{*}{$N$} & 224,418 & 224,418 & 224,418 & 224,418 & 105,635 & 105,635 & 181,974 & 181,974 \\
\hline & \multicolumn{4}{|c|}{ Firms } & \multicolumn{4}{|c|}{ Firms: Restricted Cases } \\
\hline & $(1)$ & $(2)$ & (3) & $(4)$ & $(5-A)$ & $(6-A)$ & $(7-B)$ & $(8-B)$ \\
\hline Productivity & $\begin{array}{l}0.01500 * * * \\
(0.00209)\end{array}$ & $\begin{array}{l}0.01011 \text { *** } \\
(0.00246)\end{array}$ & $\begin{array}{l}0.00566 \text { ** } \\
(0.00269)\end{array}$ & $\begin{array}{l}0.00533 \text { ** } \\
(0.00269)\end{array}$ & $\begin{array}{l}0.01460 \text { *** } \\
(0.00285)\end{array}$ & $\begin{array}{l}0.00897 \\
(0.00380)\end{array}$ & $\begin{array}{l}0.01483 \text { *** } \\
(0.00221)\end{array}$ & $\begin{array}{l}0.007628 \text { *** } \\
(0.00281)\end{array}$ \\
\hline Exporter & & & $\begin{array}{l}-0.00185 \\
(0.00337)\end{array}$ & $\begin{array}{r}-0.00173 \\
(0.00337)\end{array}$ & & $\begin{array}{l}-0.00020 \\
(0.00492)\end{array}$ & & $\begin{array}{r}-0.002079 \\
(0.00351)\end{array}$ \\
\hline Size & & $x$ & $x$ & $x$ & & $x$ & & $x$ \\
\hline NP fraction & & & $x$ & $x$ & & $x$ & & $x$ \\
\hline Multi-unit & & & & $x$ & & $x$ & & $x$ \\
\hline Industry & & & $x$ & $x$ & & $x$ & & $x$ \\
\hline Time & & & $x$ & $x$ & & $x$ & & $x$ \\
\hline State & & & & $x$ & & $x$ & & $x$ \\
\hline$R^{2}$ & 0.000 & 0.000 & 0.012 & 0.012 & 0.000 & 0.013 & 0.012 & 0.012 \\
\hline$N$ & 117,393 & 117,393 & 117,393 & 117,393 & 59,542 & 59,542 & 98,722 & 98,722 \\
\hline
\end{tabular}


Table 11: Pooled OLS Regression Characteristics on Outsourcing Status with Multinational Control

\begin{tabular}{|c|c|c|c|c|c|}
\hline Characteristic & $\begin{array}{r}\text { Outsourcing } \\
\text { dummy }\end{array}$ & $\begin{array}{r}\text { Exporting } \\
\text { dummy }\end{array}$ & $\begin{array}{r}\text { Multinat. } \\
\text { dummy }\end{array}$ & $R^{2}$ & $N$ \\
\hline \multicolumn{6}{|c|}{ Plants } \\
\hline Total employment & $\begin{array}{l}0.38239 \text { *** } \\
(0.01315)\end{array}$ & $\begin{array}{l}0.50898^{* \star \star} \\
(0.01339)\end{array}$ & 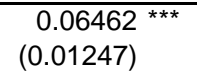 & 0.444 & 39,745 \\
\hline Total value of shipments & $\begin{array}{l}0.48067 \text { *** } \\
(0.01447)\end{array}$ & $\begin{array}{l}0.57544 \text { *** } \\
(0.01468)\end{array}$ & $\begin{array}{l}0.12834 \text { *** } \\
(0.01369)\end{array}$ & 0.408 & 39,741 \\
\hline Wage per worker & $\begin{array}{l}0.02300 * * * \\
(0.00328)\end{array}$ & $\begin{array}{l}0.06140 \text { *** } \\
(0.00346)\end{array}$ & $\begin{array}{l}0.04159 * * * \\
(0.00308)\end{array}$ & 0.507 & 39,739 \\
\hline Wage per production worker & $\begin{array}{l}0.00718 \text { * } \\
(0.00371)\end{array}$ & $\begin{array}{l}0.04816^{* * *} \\
(0.00388)\end{array}$ & $\begin{array}{l}0.04553 \text { *** } \\
(0.00351)\end{array}$ & 0.460 & 39,170 \\
\hline Wage per non-production worker & $\begin{array}{l}0.02355 \text { *** } \\
(0.00443)\end{array}$ & $\begin{array}{l}0.03148 \text { *** } \\
(0.00482)\end{array}$ & $\begin{array}{l}0.03497 \text { *** } \\
(0.00415)\end{array}$ & 0.367 & 39,703 \\
\hline Shipments per worker & $\begin{array}{l}0.12138^{* * *} \\
(0.00781)\end{array}$ & $\begin{array}{l}0.09805 \text { *** } \\
(0.00811)\end{array}$ & $\begin{array}{l}0.06787^{* * *} \\
(0.00727)\end{array}$ & 0.530 & 39,741 \\
\hline Value added per worker & $\begin{array}{l}0.07207^{* * *} \\
(0.00920)\end{array}$ & $\begin{array}{l}0.14581 \text { *** } \\
(0.00981)\end{array}$ & $\begin{array}{l}0.10529 \text { *** } \\
(0.00899)\end{array}$ & 0.298 & 39,745 \\
\hline Capital per worker & $\begin{array}{l}0.07119 \text { *** } \\
(0.01022)\end{array}$ & $\begin{array}{l}0.10740 \text { *** } \\
(0.01099)\end{array}$ & $\begin{array}{l}0.16935 \text { *** } \\
(0.00996)\end{array}$ & 0.494 & 39,745 \\
\hline Investment per worker & $\begin{array}{l}0.09071 \text { *** } \\
(0.01562)\end{array}$ & $\begin{array}{l}0.09463 \text { *** } \\
(0.01663)\end{array}$ & $\begin{array}{l}0.14820 \text { *** } \\
0.01507\end{array}$ & 0.264 & 37,296 \\
\hline $\begin{array}{l}\text { Nonproduction workers in total } \\
\text { employment }\end{array}$ & $\begin{array}{l}\begin{array}{l}0.01585 * * * \\
(0.00205)\end{array} \\
\text { Firms }\end{array}$ & $\begin{array}{l}0.03030 * \star \star \\
(0.00204) \\
\end{array}$ & $\begin{array}{r}-0.00058 \\
(0.00196) \\
\end{array}$ & 0.457 & 39,745 \\
\hline Total employment & $0^{0.68304^{\star \star \star}}$ & $\begin{array}{l}0.78603^{\text {*** }} \\
(0.03569)\end{array}$ & $\begin{array}{l}0.39714 \text { *** } \\
(0.04270)\end{array}$ & 0.399 & 6,940 \\
\hline Total value of shipments & $\begin{array}{l}0.81002 \text { *** } \\
(0.03593)\end{array}$ & $\begin{array}{l}0.89838 \text { *** } \\
(0.03966)\end{array}$ & $\begin{array}{l}0.46822 \text { *** } \\
(0.04686)\end{array}$ & 0.475 & 6,940 \\
\hline Wage per worker & $\begin{array}{l}0.01617 \text { ** } \\
(0.00778)\end{array}$ & $\begin{array}{l}0.07026 \text { *** } \\
(0.00917)\end{array}$ & $\begin{array}{l}0.02676 \text { *** } \\
(0.00832)\end{array}$ & 0.548 & 6,939 \\
\hline Wage per production worker & $\begin{array}{r}0.00745 \\
(0.00854)\end{array}$ & $\begin{array}{l}0.05594 \text { *** } \\
(0.00998)\end{array}$ & $\begin{array}{l}0.01962 \text { ** } \\
(0.00951)\end{array}$ & 0.524 & 6,886 \\
\hline Wage per non-production worker & $\begin{array}{l}-0.00038 \\
(0.01082)\end{array}$ & $\begin{array}{l}0.06230 \text { *** } \\
(0.01249)\end{array}$ & $\begin{array}{r}0.00664 \\
(0.01051)\end{array}$ & 0.215 & 6,937 \\
\hline Shipments per worker & $\begin{array}{l}0.12267 \\
(0.01634)\end{array}$ & $\begin{array}{l}0.10741 \text { *** } \\
(0.01892)\end{array}$ & $\begin{array}{l}0.06858 \text { *** } \\
(0.01776)\end{array}$ & 0.495 & 6,940 \\
\hline Value added per worker & $\begin{array}{l}0.09211 \text { *** } \\
(0.01853)\end{array}$ & $\begin{array}{l}0.15204 \text { *** } \\
(0.02219)\end{array}$ & $\begin{array}{l}0.10396 \text { *** } \\
(0.02087)\end{array}$ & 0.401 & 6,940 \\
\hline Capital per worker & $\begin{array}{l}0.10770 \text { *** } \\
(0.02150)\end{array}$ & $\begin{array}{l}0.14079 \text { *** } \\
(0.02532)\end{array}$ & $\begin{array}{l}0.07669 * * * \\
(0.02385)\end{array}$ & 0.589 & 6,940 \\
\hline Investment per worker & $\begin{array}{l}0.10451 \text { *** } \\
(0.03217)\end{array}$ & $\begin{array}{l}0.16245 \text { *** } \\
(0.03772)\end{array}$ & $\begin{array}{r}0.02647 \\
(0.03417)\end{array}$ & 0.405 & 6,796 \\
\hline $\begin{array}{l}\text { Nonproduction workers in total } \\
\text { employment }\end{array}$ & $\begin{array}{l}0.0118818 \text { *** } \\
(0.00455)\end{array}$ & $\begin{array}{l}0.0176772 \text { *** } \\
(0.00497)\end{array}$ & $\begin{array}{l}0.0138699 * * * \\
(0.00498)\end{array}$ & 0.534 & 6,940 \\
\hline
\end{tabular}

Note: Coefficients from a pooled regression on outsourcing dummy. Each regression includes a time dummy, Huber-White consistent standard errors, and corrects for within group dependence over time. ${ }^{* \star *},{ }^{\star *}$, and * represent 1,5 , and $10 \%$ significance respectively. Controls are added for size (except for shipments and employment specifications), industry, state, and multi-unit status. 
Table 12: Productivity Change Regressions--Firms

\begin{tabular}{|c|c|c|c|c|c|c|}
\hline \multicolumn{7}{|c|}{ Firms } \\
\hline & (4) & $(4-M N)$ & $(6-A)$ & $(6-A-M N)$ & $(8-B)$ & $(8-B-M N)$ \\
\hline Outsource & $\begin{array}{r}-0.0019 \\
(0.00440)\end{array}$ & $\begin{array}{r}-0.0019 \\
(0.00440)\end{array}$ & $\begin{array}{r}-0.0018 \\
(0.00617)\end{array}$ & $\begin{array}{r}-0.0017 \\
(0.00616)\end{array}$ & $\begin{array}{r}0.0038 \\
(0.00476)\end{array}$ & $\begin{array}{r}0.0038 \\
(0.00477)\end{array}$ \\
\hline Size & $\begin{array}{l}0.0057 \text { *** } \\
(0.0020)\end{array}$ & $\begin{array}{l}0.0057^{* \star *} \\
(0.0021)\end{array}$ & $\begin{array}{l}0.0070^{* * *} \\
(0.00267)\end{array}$ & $\begin{array}{l}0.0071 \text { *** } \\
(0.00273)\end{array}$ & $\begin{array}{c}0.00611^{* * *} \\
(0.00222)\end{array}$ & $\begin{array}{c}0.0061 \\
(0.00228)\end{array}$ \\
\hline Exporter & $\begin{array}{r}0.0008 \\
(0.0062)\end{array}$ & $\begin{array}{r}0.0008 \\
(0.0062)\end{array}$ & $\begin{array}{r}-0.0026 \\
(0.0092)\end{array}$ & $\begin{array}{r}-0.0026 \\
(0.0092)\end{array}$ & $\begin{array}{r}-0.0019 \\
(0.00660)\end{array}$ & $\begin{array}{r}-0.0020 \\
(0.00660)\end{array}$ \\
\hline $\begin{array}{l}\text { Multi- } \\
\text { national }\end{array}$ & & $\begin{array}{r}-0.0007 \\
(0.0045)\end{array}$ & & $\begin{array}{l}-0.0008 \\
(0.0057)\end{array}$ & & $\begin{array}{r}0.0007 \\
(0.0048)\end{array}$ \\
\hline$R^{2}$ & 0.017 & 0.017 & 0.019 & 0.019 & 0.020 & 0.020 \\
\hline$N$ & 33,087 & 33,087 & 17,819 & 17,819 & 27,233 & 27,233 \\
\hline \multicolumn{7}{|c|}{$\begin{array}{l}\text { Results of Chi-Squared Test on Bootstrap Sample (1000 repetitions) } \\
\text { Test of Difference between Outsourcing Coefficient for Two Specifications }\end{array}$} \\
\hline & $\begin{array}{l}\text { Ho: } \beta-\beta=0 \\
\text { p-value }\end{array}$ & $\begin{array}{l}(8)-(8) \mathrm{MN} \\
0.9546\end{array}$ & $\begin{array}{l}\text { Ho: } \beta-\beta=0 \\
\text { p-value }\end{array}$ & $\begin{array}{l}\text { (8)A-(8A)MN } \\
0.9268\end{array}$ & $\begin{array}{l}\text { Ho: } \beta-\beta=0 \\
\text { p-value }\end{array}$ & $\begin{array}{l}\text { (8)B-(8B)MN } \\
0.8660\end{array}$ \\
\hline
\end{tabular}

Note: Each above specification controls for industry, state, skilled labor fraction, and time, in addition to the above variates. Each regression uses Huber-White consistent standard errors and corrects for within group dependence over time. ***, **, and * represent 1,5 , and $10 \%$ significance respectively. 